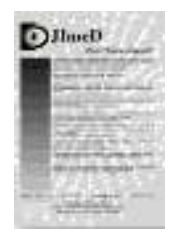

Jurnal Imejing Diagnostik (JImeD) 6 (2020) 11-15

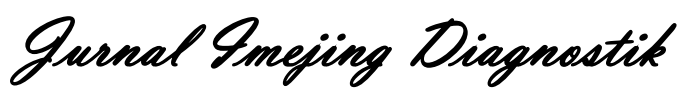

e-ISSN 2621-7457, p-ISSN 2356-301X

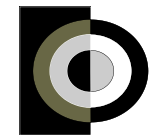

http://ejournal.poltekkes-

smg.ac.id/ojs/index.php/jimed/index

\title{
Pengaruh Variasi Arus Tabung terhadap Kontras pada Pesawat Sinar-X High Generator
}

\author{
Asih Puji Utami, Dewi Ari Mulyani, Anisa Nur Istiqomah \\ Universitas 'Aisyiyah Yogyakarta
}

Corresponding author: Asih Puji Utami

Email: asihpujiutami@unisayogya.ac.id

Received: November $16^{\text {th }}, 2019$; Revised: January $31^{\text {th }}, 2020$; Accepted: January $31^{\text {th }}, 2020$

\begin{abstract}
Background: The use of exposure factors with high voltage / $\mathrm{kV}$ and low tube current / milliAmpere (mA) will provide a low radiation dose to the patient and radiographic results that provide good contrast and can reduce the onset of geometric movements. This research is to find out and study the variation of tube current/ milliAmpere (mA) on the image quality and radiation dose received by patients in the Radiology laboratory of Aisyiyah University, Yogyakarta.

Methods: This type of research is an experimental study with a quantitative inferential approach, conducted at the Radiology Laboratory of the University of 'Aisyiyah Yogyakarta. The independent variable is the tube current variation (32 and $100 \mathrm{~mA}$ ), the dependent variable is the contras. Data collection was carried out by exposing the radiographic phantom and measuring the radiation dose with the Ray Safe X2 device. Radiograph results were analyzed by contras radiograph. Then the results will be analyzed using descriptive statistical analysis and linear regression. by testing the regression line hypothesis, the statistical test $\mathrm{f}$, the statistical test $t$, the coefficient of determination.

Results: The results showed that there was an influence of changes in tube currents (100 and $32 \mathrm{~mA}$ ) on Soft tissue-air contrast. While the change in tube current (100 mA and 32mA) does not affect the bone-Soft tissue contrast. In order to reduce the radiation dose received by the patient, it can use a low $\mathrm{mA}$ value while still being able to maintain the quality of the image.

Conclusions: No influence of $\mathrm{mA}$ change (100 and 32) on bone contrast-Soft tissue and there is the influence of $\mathrm{mA}$ changes (100 and 32) on the contrast of Soft tissue-air.
\end{abstract}

Keyword: Tube Current; Contras Radiograph; Radiation Dose.

\section{Pendahuluan}

Radiologi adalah cabang atau ilmu yang berhubungan dengan studi dan penerapan seperti sinar-x dan radiasi untuk mendiagnosa dan mengobati penyakit dengan memanfaatkan radiasi pengion. Radiasi pengion tak selamanya berbahaya bagi kesehatan jika diolah dan di gunakan dengan baik sesuai dengan undang-undang yang berlaku. Dalam bidang kesehatan, radiasi dapat memberikan suatu informasi dari tubuh manusia sehingga dokter dapat melakukan tindakan secara benar sesuai dengan informasi yang didapatkan. Informasi tersebut merupakan hasil dari pemeriksaan penunjang pemotretan di Radiologi. Ilmu yang mempelajari tentang tata cara pemotretan dengan menggunakan sinar-x untuk membuat gambar radiografi yang baik, dan dapat menegakkan diagnosa dinamakan Teknik Radiografi (Sinaga, 2006).

Pada pemeriksaan radiografi dibutuhkan faktorfaktor yang dapat mempengaruhi kualitas foto agar mendapatkan hasil yang bagus. Faktor-faktor tersebut diantaranya adalah faktor eksposi. Faktor eksposi terdiri dari tegangan listrik $(\mathrm{kV})$, Arus tabung $(\mathrm{mA})$ dan waktu (s). Tegangan listrik $(\mathrm{kV})$ adalah satuan beda potensial yang diberikan antara katoda dan anoda didalam tabung Roentgen. $\mathrm{kV}$ atau Tegangan listrik akan menentukan kualitas sinar- $x$ dan daya tembus sinar- $x$, makin tinggi besaran tegangan listrik yang di gunakan makin besar pula daya tembusnya (Bushong, 2013). Dalam menentukan tegangan listrik sebaiknya menggunakan tegangan optimal yang mampu menghasilkan detail obyek tampak jelas. Hal-hal yang mempengaruhi tegangan tabung adalah: Jenis 
pemotretan, Ketebalan obyek, Jarak pemotretan, Perlengkapan yang digunakan (Padang \& 2010, n.d.).

Faktor yang lain adalah arus dan waktu adalah perkalian arus listrik (mA) dan waktu exposi (s). Besaran arus ini menentukan kuantitas radiasi. Dalam setiap pemotretan pada berbagai bagian tubuh mempunyai besaran arus dan waktu tertentu. Pada dasarnya arus tabung yang dipilih adalah pada $\mathrm{mA}$ yang paling tinggi yang dapat dicapai oleh pesawat, agar waktu exposi dapat sesingkat mungkin, sehingga dapat mencegah kekaburan gambar yang disebabkan oleh pergerakan (Nuklir, 2013). Namun adakalanya pemeriksaan radiografi menggunakan mAs yang rendah dan menggunakan $\mathrm{kV}$ yang tinggi. Sebagai contoh pemeriksaan yang menggunakan teknik $\mathrm{kV}$ tinggi dan $\mathrm{mAs}$ rendah adalah :

1. Radiografi thorax karena loss opacitas, iga dan penetrasi effektif dari mediastinum didapatkan informasi general survey yang lebih banyak (kelainan dibawah iga terlihat)

2. Saluran Pencernaan karena diperlukan waktu yang singkat sehingga effektif menahan pergerakan (movement unsharpness) sehingga menggunakan fokus kecil.

3. Pada obstetric radiography, dosis yang diterima ibu dan anak berkurang

4. Pada HSG dosis radiasi dapat dikurangi

5. Angiography karena eksposi yang singkat sangat dibutuhkan

6. Pada serial examination, karena penggunaan waktu yang singkat dan dapat mengurang pemanasan tube.

7. Pada proyeksi lateral lumbal-sacral, dapat terlihat karena perbedaan range densiti yang besar (Marpaung, 2006).

Keuntungan penggunaan mAs yang rendah salah satunya adalah dosis radiasi yang diterima oleh pasien semakin rendah. Berdasarkan Peraturan Kepala Bapeten Nomor 8 tahun 2011 tentang keselamatan radiasi dalam penggunaan sinar- $X$ radiologi diagnostik dan intervensional, pada pasal 43 ayat 1 poin $b$ disebutkan bahwa pesawat sinar- $X$ untuk pemeriksaan umum secara rutin harus mempunyai spesifikasi : kuat arus tabung paling rendah $50 \mathrm{~mA}$ (lima puluh miliamper)(Nuklir, 2011). Namun adakalanya pesawat sinarX memiliki spesifikasi $\mathrm{mA}$ yang lebih rendah dari $50 \mathrm{~mA}$. Untuk itu penulis ingin melakukan pengkajian dan eksperimen melakukan pemeriksaan radiografi dengan menggunakan faktor eksposi $\mathrm{kV}$ tinggi dan $\mathrm{mAs}$ yang rendah. Selain dosis yang diterima pasien rendah, hasil radiografi akan memiliki contras radiografi yang baik serta dapat mengurangi adanya geometric movement (Tjahyono, 2005).

Berdasarkan latar belakang tersebut penulis akan mengkaji lebih lanjut terkait penggunaan variasi tegangan tabung waktu penyinaran sinar-x terhadap kualitas citra yaitu kontras radiograf.

\section{Metode}

Jenis penelitian yang digunakan dalam penelitian ini adalah penelitian eksperimen dengan pendekatan kuantitatif inferensial. Variabel bebasnya adalah variasi mA (100 dan $32 \mathrm{~mA})$. Sedangkan variable terikatnya adalah Kualitas Citra (densitas dan kotras) dan dosis radiasi. Pengambilan sampel dalam penelitian ini adalah dengan melakukan eksposi sebanyak 4 kali, maisng-maisng radiograf diambil nilai densitasnya pada 15 titik, kemudian dianalisa secara deskriptif, dan analisa bivariate menggunakan regresi linier untuk mengetahui pengaruhnya (Alfabeta \& 2006, n.d.).

\section{Hasil dan Pembahasan}

Alat yang digunakan :

1. Pesawat sinar-x high generator (DR) merek Samsung

2. Alat pengukur dosis Ray Safe Unit

3. Panthom antebrachi

4. Alat-alat tulis : buku, pulpen, dan mistar

5. Form hasil pengujian

6. Pedoman observasi/ alat dokumentasi

Langkah-langkah penelitian adalah :

1. Mempersiapkan semua alat yangdibutuhkan

2. Menyalakan pesawat sinar-X high generator

3. Persiapkan detector yang siap pakai dan workstation untuk mengolah data

4. Atur panthom antebrachi di atas meja pemeriksaan untuk dilakukan eksposi

5. Melakukan eksposi sebanyak 4 kali untuk mengetahui kualitas citra

6. Selanjutnnya melakukan pengolahan data. Dengan melakukan pengukuran densitas pada tiap radiograf diambil 15 titik pengukuran dengan dibagi menjadi 3 kategori yaitu tulang, Soft tissue dan udara. Kemudian di rata-rata. 


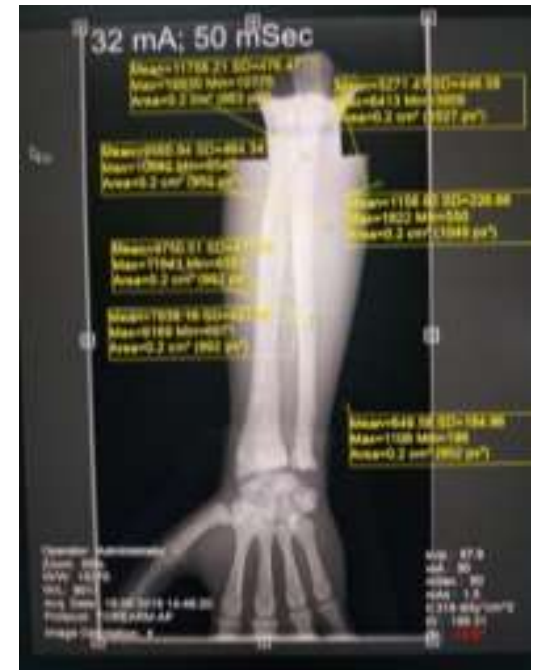

Gambar 1. Hasil Radiograf dengan faktor eksposi 58 $\mathrm{kV}, 32 \mathrm{~mA}, 50 \mathrm{msec}$

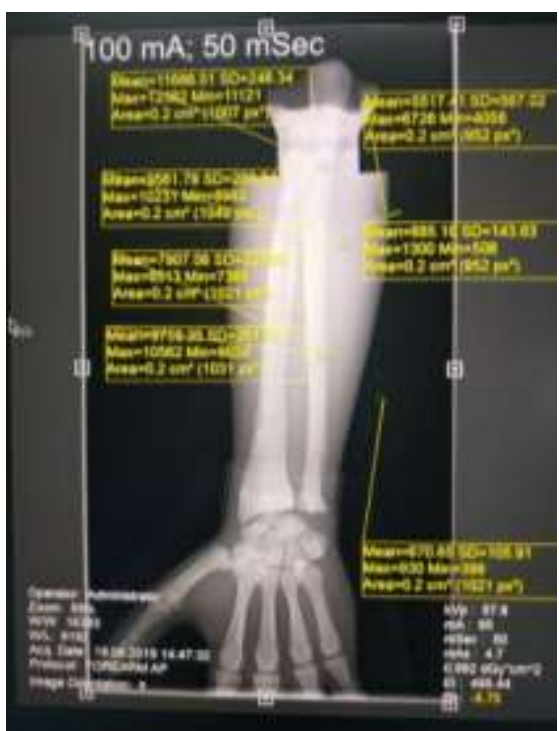

Gambar 2. Hasil Radiograf dengan faktor eksposi 58 $\mathrm{kV}, 100 \mathrm{~mA}, 50 \mathrm{msec}$

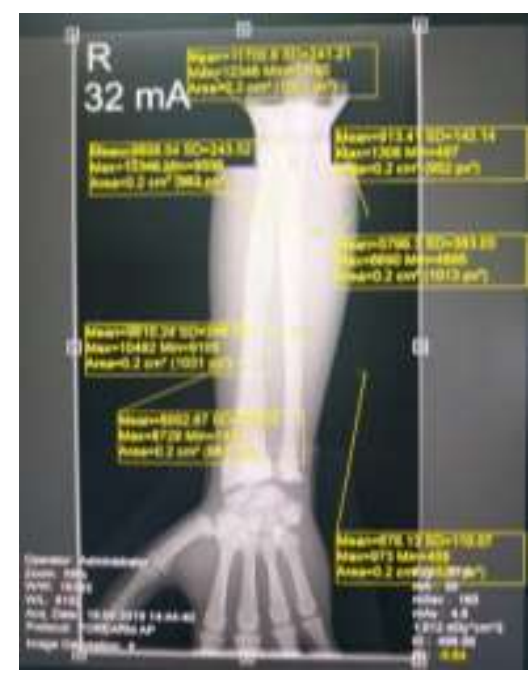

Gambar 3. Hasil Radiograf dengan faktor eksposi 58 $\mathrm{kV}, 32 \mathrm{~mA}, 5 \mathrm{mAs}$

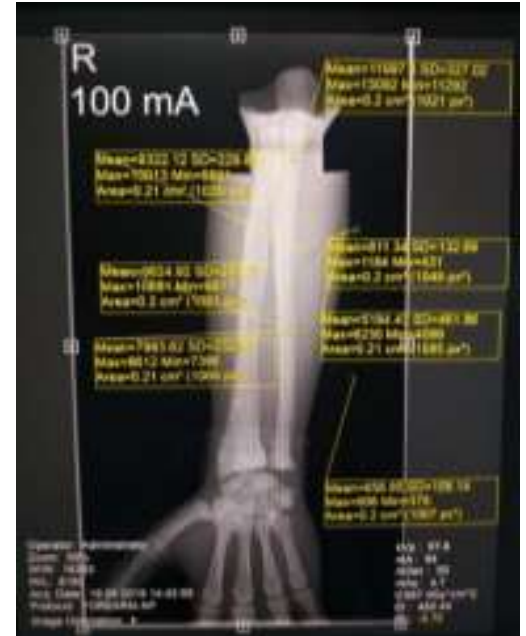

Gambar 4. Hasil Radiograf dengan faktor eksposi 58 $\mathrm{kV}, 100 \mathrm{~mA}, 5 \mathrm{mAs}$

Tabel 1. Variasi mA dan Kontras pada Tulang dan Soft tissue dengan Menggunakan $5 \mathrm{mAs}$ dan $50 \mathrm{msec}$

\begin{tabular}{ccc}
\hline $\begin{array}{c}\text { Variasi } \\
\mathrm{mA}\end{array}$ & $\begin{array}{c}\text { Nilai Contras } \\
\text { tulang-Soft tissue }(5 \\
\mathrm{mAs})\end{array}$ & $\begin{array}{c}\text { Nilai Contras } \\
\text { tulang-Soft tissue } \\
(50 \mathrm{msec})\end{array}$ \\
\hline $100 \mathrm{~mA}$ & 1841.3 & 1852.29 \\
\hline $32 \mathrm{~mA}$ & 1807.37 & 1811.35 \\
\hline
\end{tabular}

Berdasarkan Tabel 1 bahwa pengambilan radiograf menggunakan faktor eksposi $58 \mathrm{kV}$, dengan $5 \mathrm{mAs}$ dan $50 \mathrm{msec}$ diperoleh hasil bahwa nilai kontras tulang dengan Soft tissue dengan menggunakan $100 \mathrm{~mA}$ dan $32 \mathrm{mAs}$, semuanya mengalami mengalami kenaikan. Namun penggunaan $100 \mathrm{~mA}$ mengalami peningkatan yang lebih tinggi dibandingkan dengan menggunakan 32 $\mathrm{mA}$.

Tabel 2. Variasi mA dan Kontras pada Soft tissue dan udara dengan Menggunakan $5 \mathrm{mAs}$ dan $50 \mathrm{msec}$

\begin{tabular}{ccc}
\hline Variasi mA & $\begin{array}{c}\text { Nilai Contras Soft } \\
\text { tissue-udara } \\
(5 \mathrm{mAs})\end{array}$ & $\begin{array}{c}\text { Nilai Contras Soft } \\
\text { tissue-udara } \\
(50 \mathrm{msec})\end{array}$ \\
\hline $100 \mathrm{~mA}$ & 4373.09 & 4632.22 \\
\hline $32 \mathrm{~mA}$ & 4885.89 & 4114.55 \\
\hline
\end{tabular}

Dari tabel 2 dapat dilihat bahwa pengambilan radiograf menggunakan factor eksposi $58 \mathrm{kV}$, dengan $5 \mathrm{mAs}$ dan $50 \mathrm{msec}$ diperoleh hasil bahwa contras Soft tissue dan udara dengan menggunakan $100 \mathrm{~mA}$ mengalami kenaikan. Sedangkan bila menggunakan $32 \mathrm{mAs}$ contras Soft tissue dan udara mengalami penurunan. 


\section{Pengaruh Variasi mA (100 dan 32) terhadap Contras Tulang-Soft tissue dengan Menggunakan 58kV, 50msec}

Tabel 3. Uji F pengaruh variasi mA (100 dan 32) terhadap contras tulang-Soft tissue dengan menggunakan $58 \mathrm{kV}$

\begin{tabular}{lllll}
\hline Model & Sig. & Hasil & Kesimpulan & \\
\hline Regresi & $0.303^{\mathrm{b}}$ & Ha ditolak & $\begin{array}{l}\text { Tidak } \\
\text { pengaruh }\end{array}$ & Ada \\
\hline
\end{tabular}

Tabel 4. Uji Koefisien Determinasi pengaruh variasi mA (100 dan 32) terhadap contras tulang-Soft tissue dengan menggunakan $58 \mathrm{kV}$

\begin{tabular}{lll}
\hline Model & Adjusted $R$ Square & Hasil \\
\hline Regresi & 0.003 & $0.3 \%$ \\
\hline
\end{tabular}

Nilai $\mathrm{R}$ square yang telah disesuaikan (adjusted $R$ square) sebesar 0.003. Ini artinya bahwa $0.3 \%$ variabel dependen (contras tulang-soft tisue dengan menggunakan $58 \mathrm{kV}, 5 \mathrm{mAs}$ ) dapat dipengaruhi oleh variabel independennya (Variasi mA 100 dan 32). Sedangkan, sisany sebesar $96.7 \%$ dipengaruhi oleh variabel lain yang tidak diikutsertakan dalam model penelitian ini.

\section{Pengaruh Variasi mA (100 dan 32) terhadap Contras Soft tissue-Udara dengan Menggunakan 58kV, 50msec}

Tabel 5. Uji F pengaruh variasi mA (100 dan 32) terhadap contras soft tissue-udara dengan menggunakan $58 \mathrm{kV}$

\begin{tabular}{llll}
\hline Model & Sig. & Hasil & Kesimpulan \\
\hline Regresi & $0.000^{\mathrm{b}}$ & Ha diterima & Ada pengaruh \\
\hline
\end{tabular}

Tabel 6. Uji Koefisien Determinasi pengaruh variasi mA (100 dan 32) terhadap contras soft tissue-udara dengan menggunakan $58 \mathrm{kV}$

\begin{tabular}{lll}
\hline Model & Adjusted R Square & Hasil \\
\hline Regresi & 0.865 & $86.5 \%$ \\
\hline
\end{tabular}

Nilai R square yang telah disesuaikan (adjusted $R$ square) sebesar 0.865 . Ini artinya bahwa $86.5 \%$ variabel dependen (contras Soft tissue-udara dengan menggunakan $58 \mathrm{kV}, 5 \mathrm{mAs}$ ) dapat dipengaruhi oleh variabel independennya (Variasi mA 100 dan 32). Sedangkan, sisanya sebesar $14.5 \%$ dipengaruhi oleh variabel lain yang tidak diikutsertakan dalam model penelitian ini.

Kontras citra merupakan kemampuan untuk membedakan 2 objek yang saling berdekatan yang memiliki densitas yang berbeda. Kontras citra masih berhubungan dengan densitas citra. Suatu citra radiograf dapat dikatakan baik atau buruk salah satunya dari kontras yang dihasilkan.

Berdasarkan hasil penelitian dengan variasi $\mathrm{mA}$ (100 dan 32) dengan faktor eksposi $58 \mathrm{kV}$ dan 5 mAs yang diterapkan pada kontras tulang dan Soft tissue didapatkan hasil bahwa perubahan $\mathrm{mA}$ tidak ada pengaruhnya terhadap kontras citra. Begitu juga dengan variasi mA (100 dan 32) dengan faktor eksposi $58 \mathrm{kV}$ dan $50 \mathrm{mSec}$ tidak memberikan pengaruh terhadap perubahan kontras citra. Hal tersebut terjadi karena perbedaan nilai kerapatan antara tulang dan Soft tissue tidak terlalu tinggi sehingga perbedaan nilai densitas tulang dan densitas Soft tissue masih dapat dinilai dengan baik.

Pada kontras Soft tissue dan udara terdapat pengaruh perubahan $\mathrm{mA}$ (100 dan 32) sebesar $80,9 \%$ pada faktor eksposi $58 \mathrm{kV}, 5 \mathrm{mAs}$ dan $86,5 \%$ pada $58 \mathrm{kV}, 50 \mathrm{mSec}$. Nilai $\mathrm{mA}$ yang berpengaruh terhadap densitas akan mempengaruhi perbedaan kontras pada kedua organ tersebut ditambah dengan nilai kerapatan Soft tissue dan udara yang sangat berbeda.

\section{Simpulan}

1. Tidak terdapat pengaruh perubahan $\mathrm{mA}(100$ dan 32) terhadap kontras tulang-Soft tissue.

2. Terdapat pengaruh perubahan $\mathrm{mA}$ (100 dan 32) terhadap kontras Soft tissue-udara.

\section{Daftar Pustaka}

Alfabeta, D. S.-B. CV., \& 2006, undefined. (n.d.). Statistika untuk penelitian.

Bushong, S. C. (2013). Radiologic Science for Technologist: Physics, Biology, and Protection.

Marpaung, T. (2006). Proteksi Radiasi dalam Radiologi Intervensional. Seminar Keselamatan Nuklir, 725-745.

Nuklir, K. B. P. T. (2011). Peraturan Kepala Badan Pengawas Tenaga Nuklir Nomor 8 Tahun 2011.

Nuklir, K. B. P. T. (2013). Peraturan Kepala Badan Pengawas Tenaga Nuklir Nomor 4 Tahun 2013.

Padang, O. P.-U. B., \& 2010, undefined. (n.d.). Fisika Radiasi.

Sinaga, M. (2006). Tantangan Badan Pengawas Mengimplementasikan Peraturan Penggunaan Pesawat Sinar X Untuk Diagnostik. Seminar Keselamatan Nuklir, 29-37. 
Tjahyono, H. H. (2005). Sistem Pencacah Berbasis

Komputer. Widyanuklida, 6(2), 26-38. 